\title{
Anti-angiogenic effect of arsenic trioxide in lung cancer via inhibition of endothelial cell migration, proliferation and tube formation
}

\author{
MENG-HANG YANG $^{1 *}$, KE-JIE CHANG ${ }^{1 *}$, JIN-CHENG ZHENG $^{1}$, HAI HUANG $^{1}$, \\ GUANG-YUAN SUN ${ }^{2}$, XUE-WEI ZHAO ${ }^{2}$, BING LI $^{1}$ and QING-YU XIU ${ }^{1}$ \\ Departments of ${ }^{1}$ Respiratory Medicine and ${ }^{2}$ Thoracic Surgery, Shanghai Changzheng \\ Hospital, Second Military Medical University, Shanghai 200003, P.R. China
}

Received September 22, 2015; Accepted March 10, 2017

DOI: $10.3892 / \mathrm{ol} .2017 .6518$

\begin{abstract}
Arsenic trioxide $\left(\mathrm{As}_{2} \mathrm{O}_{3}\right)$ exhibits a remarkable effect on leukemia treatment; however, its effect on solid tumors remains poorly explored. The present study demonstrated the inhibitory effect of $\mathrm{As}_{2} \mathrm{O}_{3}$ on lung cancer and explored its possible mechanism. It was observed that $\mathrm{As}_{2} \mathrm{O}_{3}$ significantly inhibited the growth of lung cancer xenografts and tumor angiogenesis in vivo. The inhibitory effect of $\mathrm{As}_{2} \mathrm{O}_{3}$ on cell proliferation in vitro was more remarkable in vascular endothelial cells than in lung cancer cells. It was also observed that $\mathrm{As}_{2} \mathrm{O}_{3}$ inhibited the migration of vascular endothelial cells and disrupted vascular tube formation on Matrigel assays. In addition, a series of key signaling factors involved in multiple stages of angiogenesis, including matrix metalloproteinase (MMP)-2, MMP-9, platelet-derived growth factor (PDGF)-BB/PDGF receptor- $\beta$, vascular endothelial growth factor (VEGF)-A/VEGF receptor-2, basic fibroblast growth factor (FGF)/FGF receptor-1 and delta like canonical Notch ligand 4/Notch-1, were regulated by $\mathrm{As}_{2} \mathrm{O}_{3}$. These findings suggested that anti-angiogenesis may be an underlying mechanism of $\mathrm{As}_{2} \mathrm{O}_{3}$ anticancer activity in lung cancer.
\end{abstract}

\section{Introduction}

Arsenic trioxide $\left(\mathrm{As}_{2} \mathrm{O}_{3}\right)$ is a common drug in traditional Chinese medicine (1). Since the remarkable therapeutic

Correspondence to: Dr Bing Li or Dr Qing-Yu Xiu, Department of Respiratory Medicine, Shanghai Changzheng Hospital, Second Military Medical University, 415 Fengyang Road, Shanghai 200003, P.R. China

E-mail: bing_li1962@163.com

E-mail: xiu_qingyu@126.com

${ }^{*}$ Contributed equally

Key words: arsenic trioxide, lung cancer, angiogenesis, vascular endothelial cells, signaling factors effect of $\mathrm{As}_{2} \mathrm{O}_{3}$ on acute promyelocytic leukemia (APL) was recognized (2), an increasing number of researchers have reported its potential anticancer activity in solid tumors, including hepatocellular carcinoma $(3,4)$, and pancreatic (5), prostate (6) and cervical cancer (7). However, the effect of $\mathrm{As}_{2} \mathrm{O}_{3}$ on lung cancer, which is the leading cause of cancer mortality worldwide (8), has been poorly explored. Furthermore, the majority of studies on $\mathrm{As}_{2} \mathrm{O}_{3}$ anticancer effects were performed on cancer cell lines, and only a few in vivo studies were reported (9-12). Among the known mechanisms of the anticancer action of $\mathrm{As}_{2} \mathrm{O}_{3}$, anti-angiogenesis is an important characteristic of $\mathrm{As}_{2} \mathrm{O}_{3}$. Several studies have reported that $\mathrm{As}_{2} \mathrm{O}_{3}$ could influence tumor angiogenesis $(6,13,14)$, but the underlying mechanism remains unclear.

Angiogenesis, the process of new blood vessel formation, is the key step in solid tumor development; it is necessary in tumor growth, invasion and metastasis (15). According to the classical theory of tumor angiogenesis, tumors obtain nutrients and oxygen by diffusion in the early stage, but when the tumor size becomes larger, diffusion can no longer meet the tumor's requirement of oxygen and nutrients; thus, the angiogenesis process is initiated (16). The angiogenesis process in solid tumors can be summarized as follows: Continuing growth of a tumor promotes the so-called 'angiogenic switch' in the microenvironment, which initiates the angiogenic process $(17,18)$. Matrix metalloproteinases (MMPs) induce the degradation and remodeling of the extracellular matrix (ECM) (19-21), and endothelial cells migrate through the remodeled ECM, induced by platelet-derived growth factor (PDGF) and chemokines $(22,23)$. Due to the role of vascular endothelial growth factor (VEGF) and fibroblast growth factor (FGF), endothelial cells greatly proliferate (24-26). Meanwhile, tube-like structure formation and vascular function are achieved by delta like canonical Notch ligand 4 (Dl14)/Notch-1 signaling (27-30). Tumor angiogenesis is a complex process that includes multiple stages and is regulated by numerous signaling molecules that interact with one another (18). Currently, inhibition of angiogenesis has become an important target in the treatment of solid tumors, including lung cancer $(31,32)$. Each stage of the angiogenic process and the relevant signal factors involved in the whole process 
of angiogenesis may become potential therapeutic targets. Several anti-angiogenic agents have been approved by the Food and Drug Administration (FDA) for cancer treatment, such as bevacizumab, a humanized anti-VEGF-A monoclonal antibody, and the tyrosine kinase inhibitors sorafenib and sunitinib, targeting VEGF receptors (VEGFRs) (31,32). These drugs may inhibit the proliferation of endothelial cells without influencing other stages of angiogenesis.

Our group has previously demonstrated that $\mathrm{As}_{2} \mathrm{O}_{3}$ exhibits anti-lung cancer activity by inhibiting angiogenesis (33). It was also demonstrated that $\mathrm{As}_{2} \mathrm{O}_{3}$ could reduce malignant pleural effusion caused by the pleural metastasis of lung cancer by downregulating nuclear factor- $\kappa \mathrm{B}$, tumor necrosis factor- $\alpha$ and VEGF-A (34). In the present study, the antitumor activity and anti-angiogenic effect of $\mathrm{As}_{2} \mathrm{O}_{3}$ were demonstrated on both non-small cell lung cancer (NSCLC) and small cell lung cancer (SCLC) in vivo. The present study also revealed that $\mathrm{As}_{2} \mathrm{O}_{3}$ disrupted multiple stages of angiogenesis, including endothelial cell migration, proliferation and tube formation. In addition, a series of key signaling molecules involved in multiple stages of angiogenesis were identified to be regulated by $\mathrm{As}_{2} \mathrm{O}_{3}$. It is expected that these results would provide a basis for the application of $\mathrm{As}_{2} \mathrm{O}_{3}$ in lung cancer treatment.

\section{Materials and methods}

Cell culture. The human NSCLC cell line A549 was obtained from the Cell Bank of Chinese Academy of Sciences (Shanghai, China). The human SCLC cell line NCI-H446 and human umbilical vein endothelial cells (HUVECs), used to determine the effect of $\mathrm{As}_{2} \mathrm{O}_{3}$ on tumor angiogenesis, were obtained from the American Type Culture Collection (Manassas, VA, USA). A549 and NCI-H446 cells were cultured in a mixture of RPMI 1640 medium (HyClone; GE Healthcare Life Sciences, Logan, UT, USA), $10 \%$ fetal bovine serum (FBS) (HyClone; GE Healthcare Life Sciences), $100 \mathrm{U} / \mathrm{ml}$ penicillin and $100 \mu \mathrm{g} / \mathrm{ml}$ streptomycin. HUVECs were cultured in Dulbecco's modified Eagle's medium (HyClone; GE Healthcare Life Sciences) supplemented with $10 \%$ FBS and the same antibiotics as described above. All the cell lines were incubated in a humidified atmosphere of $5 \% \mathrm{CO}_{2}$ at $37^{\circ} \mathrm{C}$.

Xenograft models and drug treatment. A total of 40 male nude mice, $5-6$ weeks old and $\sim 18 \mathrm{~g}$ in weight, were purchased from and raised in the Experimental Animal Center of Second Military Medical University (Shanghai, China). All mice were housed at $22^{\circ} \mathrm{C}, 12$-h light/12-h dark cycle and free access to clean water and food. A total of $0.2 \mathrm{ml} \mathrm{A} 549$ or NCI-H446 cell suspension at a density of $5.0 \times 10^{7}$ cells $/ \mathrm{ml}$ was injected subcutaneously into the right flank of the mice. At 20 days post-injection, tumor volume reached $\sim 100 \mathrm{~mm}^{3}$. Mice were then randomly divided into four groups, and were treated with 2.5 or $5.0 \mathrm{mg} / \mathrm{kg} \mathrm{As}_{2} \mathrm{O}_{3}$ (i.p.) (Beijing Shuanglu Pharmaceutical Co., Ltd., Beijing, China), $30 \mathrm{mg} / \mathrm{kg}$ sorafenib (p.o.) (LC Laboratories, Woburn, MA, USA) or normal saline (NS) (i.p.) once daily for 10 days. Tumor volume was calculated as $0.5 \mathrm{xa}^{2} \mathrm{xb}^{2}$, where $\mathrm{a}$ and $\mathrm{b}$ are the largest and smallest lengths of the tumor, respectively. Animal welfare and experimental procedures were carried out in accordance with the Guide for the Care and Use of Laboratory Animals (Ministry of Science and
Technology of China) and the Experimental Animal Ethical Care Guidelines of Second Military Medical University. The animal study was approved by the Committee on Ethics of Biomedicine, Second Military Medical University.

Immunohistochemistry. Fresh tumor tissue samples were fixed in $4 \%$ paraformaldehyde solution, embedded in paraffin and cut into 5- $\mu \mathrm{m}$-thick sections. Sections were deparaffinized and blocked for endogenous peroxidase ablation. Then, sections were incubated with anti-cluster of differentiation CD31 primary antibody (1:75, catalog no. AF3628, R\&D Systems, Inc., Minneapolis, MN, USA) overnight at $4^{\circ} \mathrm{C}$ and the secondary antibody (1:200, catalog no. 14-13-06, KPL, Inc., Gaithersburg, MD, USA) for $1 \mathrm{~h}$ at room temperature. Sections were colored with 3,3'-diaminobenzidine (Dako; Agilent Technologies, Inc., Santa Clara, CA, USA) and counterstained with hematoxylin to reveal the nuclei. The quantification of microvessels was performed by counting the number of positive CD31 signals under an inverted fluorescence microscope in five random fields at $\times 200$ magnification.

Cell proliferation assay. Cells $\left(2 \times 10^{3}\right.$ cells/well) were seeded in triplicate in 96-well plates and incubated under the aforementioned culture conditions. VEGF-A (10 ng/ml; Shanghai Biomart Technology Co., Ltd., Shanghai, China) was added in the medium of HUVECs. Cells were then treated with various concentrations $\left(2.0\right.$ or $4.0 \mu \mathrm{M}$ ) of $\mathrm{As}_{2} \mathrm{O}_{3}$ (Beijing Shuanglu Pharmaceutical Co., Ltd., Beijing, China), $4.0 \mu \mathrm{M}$ sorafenib (LC Laboratories, Woburn, MA, USA) or NS. After additional 24 or $48 \mathrm{~h}$, cell proliferation was determined in triplicate, using a Cell Counting Kit-8 (CCK-8) assay (Beyotime Institute of Biotechnology, Haimen, China). The absorbance of each well at $450 \mathrm{~nm}$ was measured. The results were expressed as contrast absorbance, considering the NS group as control.

Wound-healing assay. Cells were seeded in 6-well plates and divided into four groups: Control group, $\mathrm{As}_{2} \mathrm{O}_{3} 2.0 \mu \mathrm{M}$ group, $\mathrm{As}_{2} \mathrm{O}_{3} 4.0 \mu \mathrm{M}$ group and sorafenib $4.0 \mu \mathrm{M}$ group. When cells grew to confluency, a mechanical wound was created by gently scratching the cells with a pipette tip (time $0 \mathrm{~h}$ ). Images were captured after 24 and $48 \mathrm{~h}$, and the wound healing capacity was quantified by measuring the distance between the wound edges. Experiments were carried out in triplicate wells from three independent experiments.

Vascular tube formation assay in vitro. Plates with 24 wells were firstly coated with Matrigel (BD Biosciences, Franklin Lakes, NJ, USA). Unpolymerized Matrigel was placed in the wells $(300 \mu \mathrm{l} /$ well $)$ and allowed to polymerize for $1 \mathrm{~h}$ at room temperature. HUVECs in $500 \mu 1$ medium were seeded onto the polymerized Matrigel at a density of $5 \times 10^{4}$ cells/well. VEGF-A (10 ng/ml; Shanghai Biomart Technology Co., Ltd.) and basic FGF (bFGF) (10 ng/ml; Shanghai Biomart Technology Co., Ltd.) were used as angiogenic stimuli (35). After incubation at $37^{\circ} \mathrm{C}$ in $5 \% \mathrm{CO}_{2}$ for $18 \mathrm{~h}$, images of tube formation were acquired with an inverted phase-contrast light microscope (Olympus Corporation, Tokyo, Japan) equipped with a microscope camera (Q Imaging, Surrey, BC, Canada). The degree of tube formation was quantified in five random fields from 
each well at x40 magnification, using ImageJ software (version 1.48, National Institutes of Health, Bethesda, MD, USA).

Western blotting. Total proteins were extracted from cells using radioimmunoprecipitation assay lysis buffer (Beyotime Institute of Biotechnology, Haimen, China). Aliquots containing $20 \mu \mathrm{g}$ protein were used for western blotting. Proteins were separated by SDS-PAGE (10\% gel) and transferred to polyvinylidene fluoride membranes. Membranes were blocked with a solution containing 5\% nonfat milk for $1 \mathrm{~h}$, and then incubated with the corresponding primary antibodies overnight at $4^{\circ} \mathrm{C}$. Membranes were then washed three times with TBS containing Tween-20 and incubated with the secondary antibody (1:3,000, catalog no. ab6721, Abcam, Cambridge, UK) at room temperature for $1 \mathrm{~h}$. The protein bands were detected by chemiluminescence (Western chemiluminescent horseradish peroxidase substrate, catalog no. WBKLS0500, Merck KGaA, Darmstadt, Germany). $\beta$-actin was used as an internal control. The following primary antibodies were used all at 1:1,000 dilution: Anti-MMP-2 (catalog no. ab86607, Abcam), anti-MMP-9 (catalog no. ab38898, Abcam), anti-PDGF-BB (catalog no. ab23914, Abcam), anti-PDGF receptor (PDGFR)- $\beta$ (catalog no. ab111310, Abcam), anti-VEGF-A (catalog no. ab46154, Abcam), anti-VEGFR-2 (catalog no. ab39256, Abcam), anti-bFGF (catalog no. ab8880, Abcam), anti-FGF receptor (FGFR)-1 (catalog no. ab823, Abcam), anti-D114 (catalog no. ab7280, Abcam), anti-Notch-1 (catalog no. ab27526, Abcam) and anti- $\beta$-actin (catalog no. sc-47778, Santa Cruz Biotechnology, Inc., Dallas, TX, USA).

Statistical analysis. Data were analyzed using SPSS 17.0 software (SPSS, Inc., Chicago, IL, USA). The results are presented as means \pm standard deviation, as analyzed by one-way analysis of variance, followed by Fisher's least significant difference $t$ test. $\mathrm{P}<0.05$ was considered to indicate a statistically significant difference.

\section{Results}

$\mathrm{As}_{2} \mathrm{O}_{3}$ inhibits the growth of human lung cancer xenografts and tumor angiogenesis in vivo. To determine the effect of $\mathrm{As}_{2} \mathrm{O}_{3}$ on the growth of lung cancer, xenograft tumor models were established using the NSCLC cell line A549 and the SCLC cell line NCI-H446. When all nude mice developed tumors, drug administration was performed for 10 continuous days. As presented in Fig. 1A, the mean tumor volumes in the $\mathrm{As}_{2} \mathrm{O}_{3}$ groups were significantly smaller than those in the control groups at the end of treatment, and tumor volumes in the $5.0 \mathrm{mg} / \mathrm{kg} \mathrm{As} \mathrm{O}_{3}$ group were smaller than those in the $2.5 \mathrm{mg} / \mathrm{kg} \mathrm{As} \mathrm{O}_{3}$ group. These findings were observed in both types of xenograft model. Sorafenib, an anti-angiogenic, anti-tumor agent targeting VEGFR-2 (36), was used as a positive control. It was observed that the inhibitory effect of sorafenib on tumor growth was greater than that of $5.0 \mathrm{mg} / \mathrm{kg} \mathrm{As} \mathrm{O}_{3}$ in the $\mathrm{A} 549$ xenograft model, while it was similar to that of $5.0 \mathrm{mg} / \mathrm{kg} \mathrm{As} \mathrm{O}_{3}$ in the NCI-H446 xenograft model. These results suggested that $\mathrm{As}_{2} \mathrm{O}_{3}$ had an inhibitory effect on both NSCLC and SCLC tumor growth in a dose-dependent manner.

Next, sections of xenografts were stained for CD31, which was used primarily to demonstrate the presence of endothelial cells, to detect the number and morphology of endothelial cells as a measure of tumor angiogenesis (28). Representative images of immunohistochemistry are presented in Fig. 1C, and the quantification of microvessel numbers is presented in Fig. 1B. The mean microvessel number in the two $\mathrm{As}_{2} \mathrm{O}_{3}$ groups was significantly lower than that in the control group $(\mathrm{P}<0.001)$ in both types of xenograft model. The morphology of microvessels in the $\mathrm{As}_{2} \mathrm{O}_{3}$ groups was poorly developed compared with the normal tube-like structure in the control group. The microvessel number in the sorafenib group was also significantly lower than that of the control group $(\mathrm{P}<0.001)$, but no poorly-developed vascular structures were observed in the sorafenib group. These data indicated that $\mathrm{As}_{2} \mathrm{O}_{3}$ could inhibit tumor angiogenesis in NSCLC and SCLC in a dose-dependent manner, but its mechanism may not be identical with that of sorafenib. $\mathrm{As}_{2} \mathrm{O}_{3}$ may decrease the number of blood vessels and delay the development of vascular structures, whereas sorafenib may only decrease the number of blood vessels.

$\mathrm{As}_{2} \mathrm{O}_{3}$ inhibits the proliferation of lung cancer cells and HUVECs. To further determine whether the anti-tumor effect of $\mathrm{As}_{2} \mathrm{O}_{3}$ in vivo depended on its anti-angiogenic effect or its direct cytotoxicity towards tumor cells, its effect on the proliferation of lung cancer cells and HUVECs was examined by CCK-8 assay. As presented in Fig. 2A and B, A549 and NCI-H446 cell proliferation at $24 \mathrm{~h}$ exhibited no significant difference between the groups, while at $48 \mathrm{~h}$, cell proliferation in the $\mathrm{As}_{2} \mathrm{O}_{3}$ groups was slightly lower than that in the control and sorafenib groups. $\mathrm{As}_{2} \mathrm{O}_{3}$ significantly inhibited HUVEC proliferation compared with that of the control group at both 24 and $48 \mathrm{~h}$. The inhibitory effect of sorafenib on HUVEC proliferation was also obvious (Fig. 2C). These results demonstrated that direct cytotoxicity towards tumor cells was not the main factor in the anti-lung cancer effect of $\mathrm{As}_{2} \mathrm{O}_{3}$, while inhibition of vascular endothelial cell proliferation may be important in this process.

$\mathrm{As}_{2} \mathrm{O}_{3}$ disrupts $\mathrm{HUVEC}$ migration and tube-like structure formation on Matrigel. To determine the effect of $\mathrm{As}_{2} \mathrm{O}_{3}$ on the migration of HUVECs, a wound-healing assay was performed. As presented in Fig. 3A, the wound-healing capacity of HUVECs was diminished by $\mathrm{As}_{2} \mathrm{O}_{3}$ at $24 \mathrm{~h}$ after the wounds were created, and at $48 \mathrm{~h}$ after scratching, this phenomenon was more obvious. According to the quantitative comparison of cell migration distances at $48 \mathrm{~h}$ (Fig. 3B), the distances of cell migration in the $\mathrm{As}_{2} \mathrm{O}_{3} 2$ and $4 \mu \mathrm{M}$ groups were $289.52 \pm 28.62$ and $180.00 \pm 30.90 \mu \mathrm{m}$, respectively, which were significantly lower than the cell migration distance in the control group $(509.52 \pm 29.74 \mu \mathrm{m} ; \mathrm{P}<0.001)$, suggesting that the migration of HUVECs was inhibited by $\mathrm{As}_{2} \mathrm{O}_{3}$ in a dose-dependent manner. However, the distance of cell migration in the sorafenib group $(493.33 \pm 43.74 \mu \mathrm{m})$ was not significantly different from that in the control group ( $\mathrm{P}>0.05)$, which suggested that, different from $\mathrm{As}_{2} \mathrm{O}_{3}$, sorafenib did not affect the migration of HUVECs.

Next, it was examined whether $\mathrm{As}_{2} \mathrm{O}_{3}$ was able to disrupt endothelial network formation by Matrigel assay. HUVECs were plated onto Matrigel in the presence of VEGF-A and $\mathrm{bFGF}$ as angiogenic factors (35). Then, cells were treated with 2 or $4 \mu \mathrm{M} \mathrm{As}_{2} \mathrm{O}_{3}, 4 \mu \mathrm{M}$ sorafenib, or NS as control for $18 \mathrm{~h}$, 
A

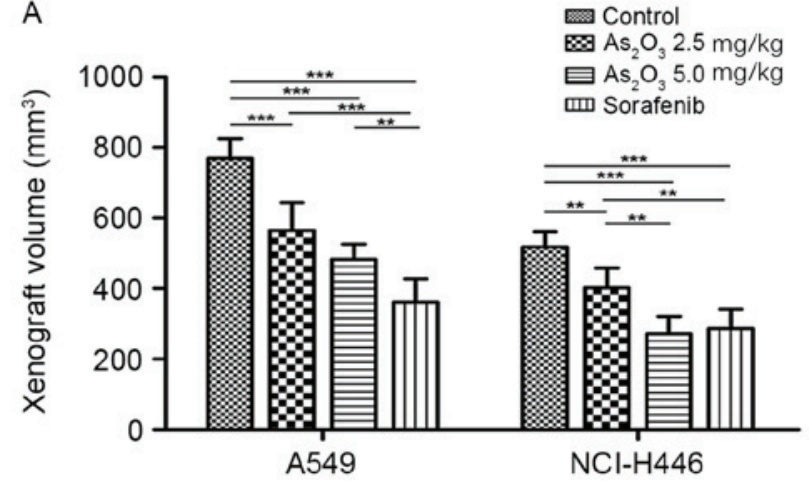

B

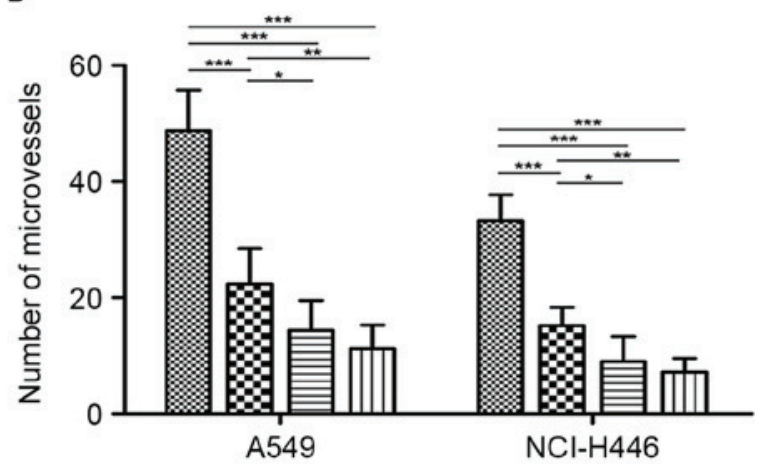

C

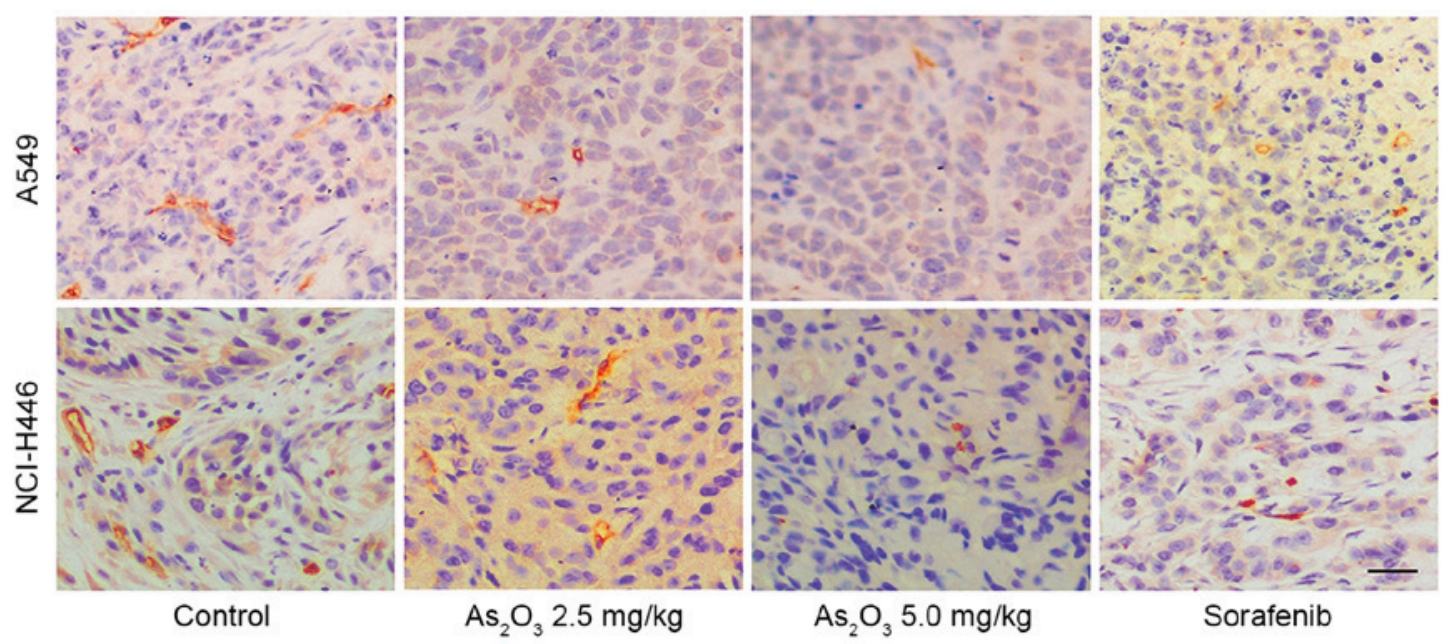

Figure 1. $\mathrm{As}_{2} \mathrm{O}_{3}$ inhibits A549 and NCI-H446 xenograft growth and tumor angiogenesis. (A) Mean tumor volumes of the four groups in the A549 and NCI-H446 tumor models following drug treatment. (B) Quantification of microvessel numbers. Error bars indicate the standard deviation. ${ }^{*} \mathrm{P}<0.05$, ${ }^{* *} \mathrm{P}<0.01$ and ${ }^{* * *} \mathrm{P}<0.001$. (C) $\mathrm{As}_{2} \mathrm{O}_{3}$ decreased the number of microvessels and induced poorly-developed vascular structures. Tumor sections were immunostained with an anti-cluster of differentiation 31 antibody (brown). Scale bar, $50 \mu \mathrm{m}$.

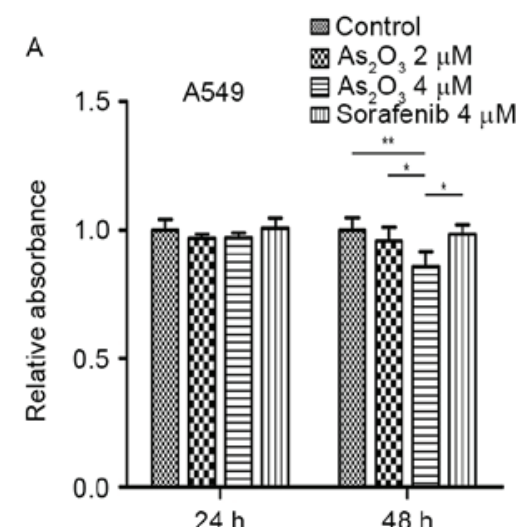

$24 \mathrm{~h}$
B

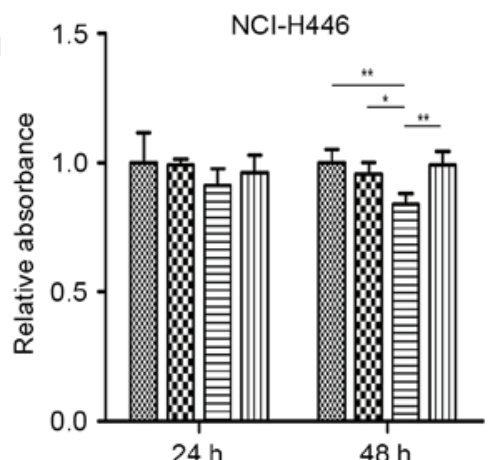

C

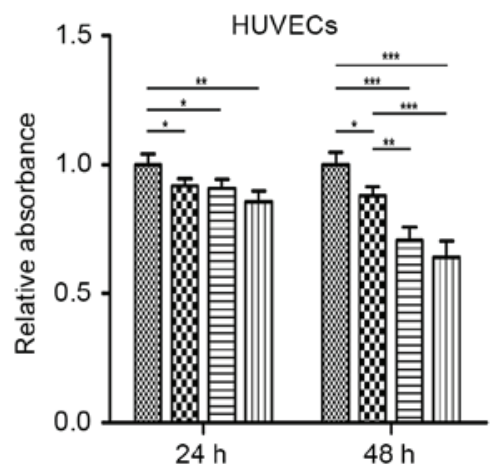

Figure 2. $\mathrm{As}_{2} \mathrm{O}_{3}$ inhibits the proliferation of lung cancer cells and HUVECs. The proliferation of (A) A549 cells, (B) NCI-H446 cells and (C) HUVECs in each group at 24 or $48 \mathrm{~h}$ was examined by Cell Counting Kit- 8 assay, and the relative absorbance was compared with that of the control group. Error bars indicate the standard deviation. ${ }^{*} \mathrm{P}<0.05,{ }^{* *} \mathrm{P}<0.01$ and ${ }^{* * *} \mathrm{P}<0.001$. HUVEC, human umbilical vein endothelial cell.

and microphotographs were then obtained (Fig. 3C). Pictures of cords of interconnecting cells were generated by ImageJ $1.48 \mathrm{v}$ software (Fig. 3D), and the number of cord formations was quantitatively analyzed (Fig. 3E). As presented in Fig. 3E, a significant decrease in tube formation in the $\mathrm{As}_{2} \mathrm{O}_{3}$ groups was observed $(\mathrm{P}<0.001)$, where normal tube structures were destroyed with interrupted alignments and cords. Sorafenib also reduced the number of cord formations $(\mathrm{P}<0.01)$, but the tube structures observed in this group were as regular as those in the control group.

$\mathrm{As}_{2} \mathrm{O}_{3}$ inhibits angiogenesis-associated factors in lung cancer cells and HUVECs. Based on the aforementioned results, $\mathrm{As}_{2} \mathrm{O}_{3}$ displayed effective anti-angiogenic activity both in vivo and in vitro. $\mathrm{As}_{2} \mathrm{O}_{3}$ could disrupt multiple stages of angiogenesis, including endothelial cell migration, 

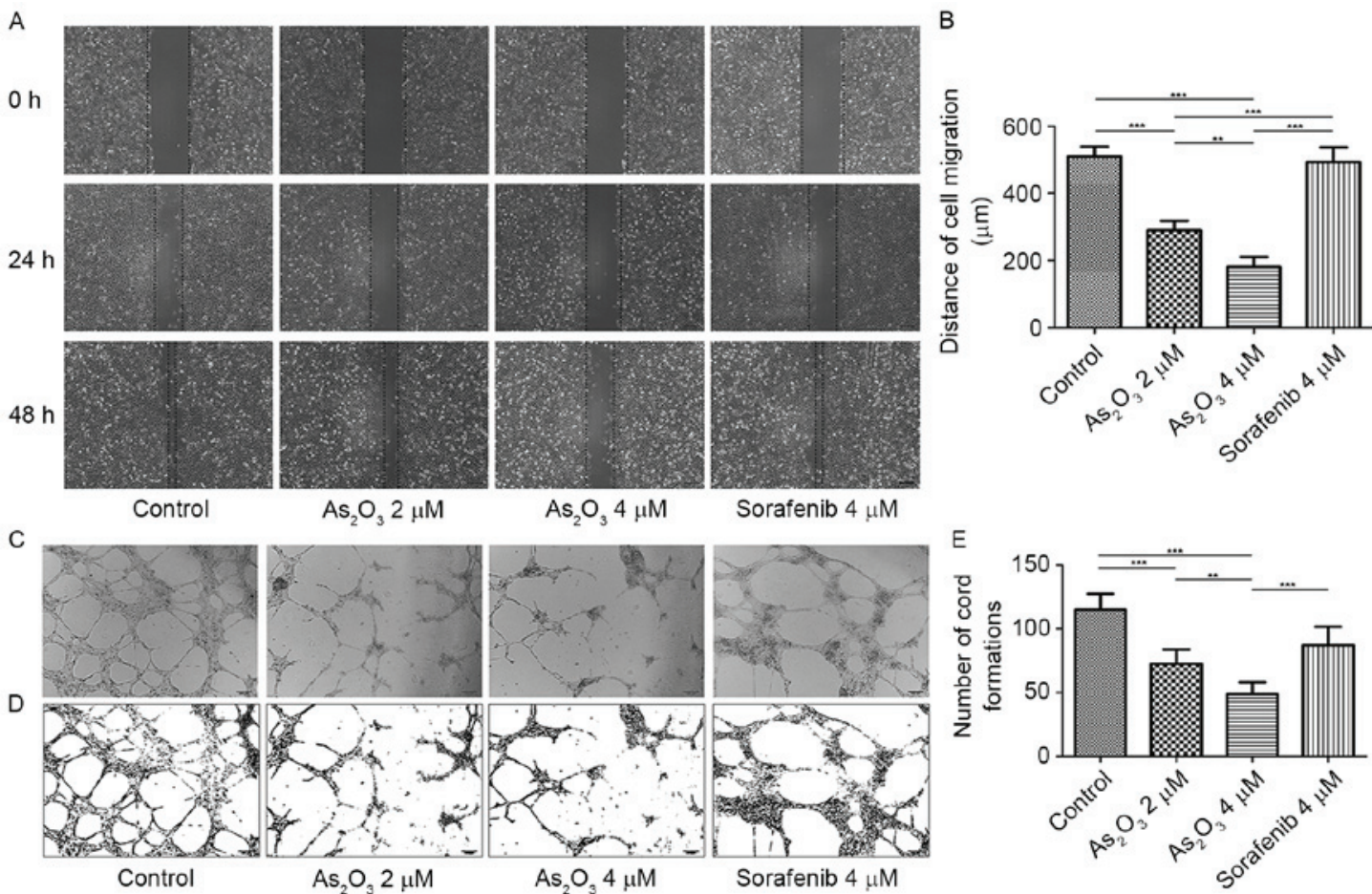

Figure 3. $\mathrm{As}_{2} \mathrm{O}_{3}$ disrupts HUVEC migration and vascular tube formation in vitro. (A) $\mathrm{As}_{2} \mathrm{O}_{3}$ diminished the wound-healing capacity of $\mathrm{HUVECs}$ at 24 and $48 \mathrm{~h}$ after scratching. Scale bars, $200 \mu \mathrm{m}$. (B) Quantification of cell migration distances at $48 \mathrm{~h}$ after scratching. (C) HUVECs plated onto Matrigel to form tube-like structures in the four groups were observed under an inverted phase-contrast microscope. Scale bars, $200 \mu \mathrm{m}$. (D) Images of cords of interconnecting cells were generated by ImageJ software (version 1.48). (E) Quantification of cord formations. Error bars indicate the standard deviation. ${ }^{* *} \mathrm{P}<0.01$ and ${ }^{* * * *} \mathrm{P}<0.001$. HUVEC, human umbilical vein endothelial cell.

A

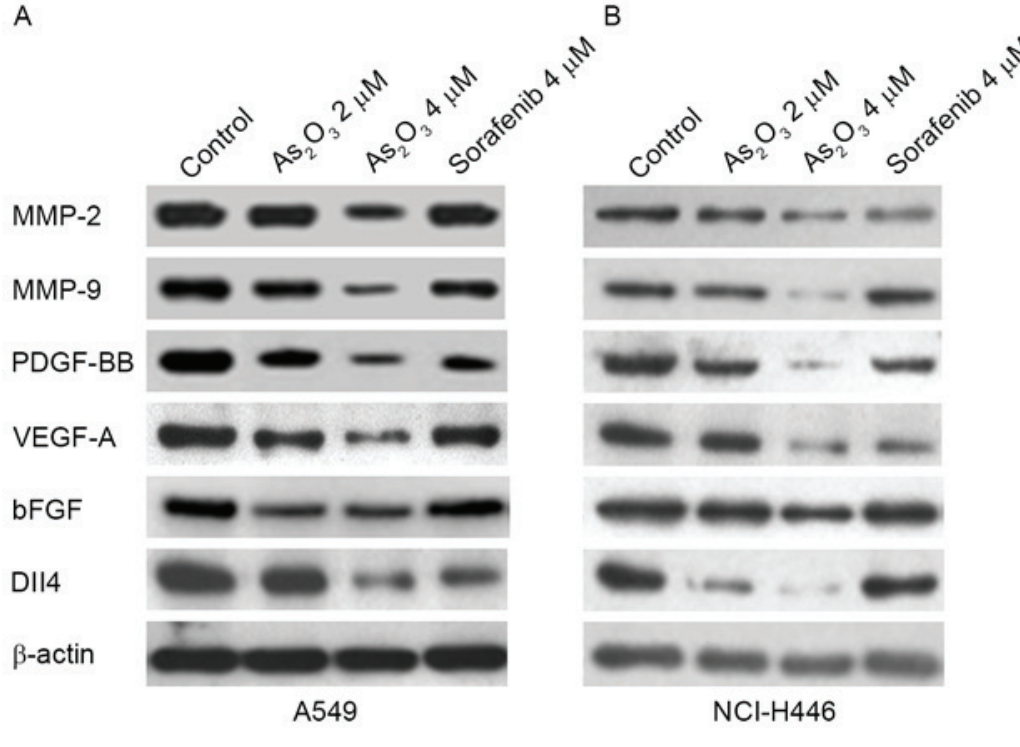

C

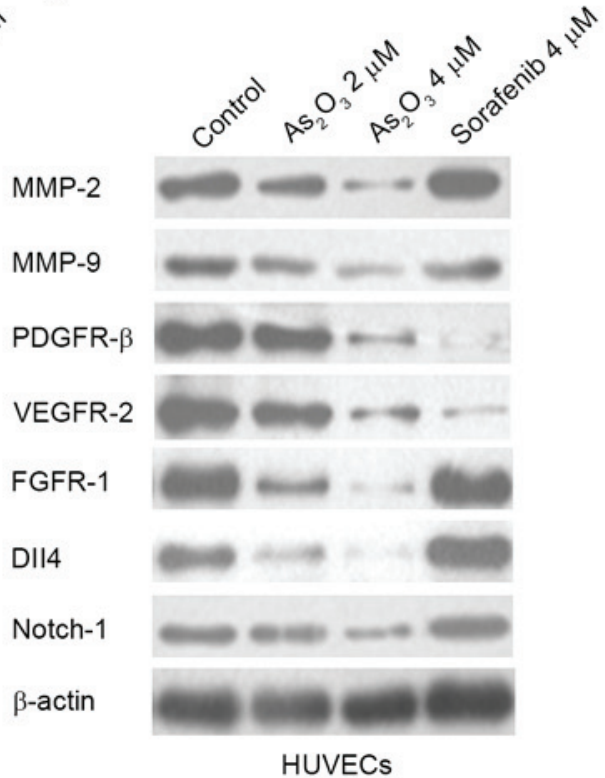

Figure 4. $\mathrm{As}_{2} \mathrm{O}_{3}$ inhibits angiogenesis-associated factors. $\mathrm{As}_{2} \mathrm{O}_{3}$ reduced MMP-2, MMP-9, PDGF-BB, VEGF-A, bFGF and Dll4 protein levels in (A) A549 and (B) NCI-H446 cells. (C) $\mathrm{As}_{2} \mathrm{O}_{3}$ reduced MMP-2, MMP-9, PDGFR- $\beta$, VEGFR-2, FGFR-1, Dl14 and Notch-1 protein levels in HUVECs. The target protein levels were evaluated by western blotting. HUVEC, human umbilical vein endothelial cell; MMP, matrix metalloproteinase; PDGFR, platelet-derived growth factor receptor; VEGFR, vascular endothelial growth factor; bFGF, basic fibroblast growth factor; FGFR, fibroblast growth factor receptor; Dll4, delta like canonical Notch ligand 4.

proliferation and tube formation. The present study next examined angiogenesis-associated factors involved in these stages at the protein level by western blotting. As presented in Fig. 4A and $\mathrm{B}, \mathrm{As}_{2} \mathrm{O}_{3}$ reduced the expression of MMP-2, MMP-9,
PDGF-BB, VEGF-A, bFGF and D114 in A549 and NCI-H446 cells. $\mathrm{As}_{2} \mathrm{O}_{3}$ also reduced the expression of MMP-2, MMP-9, PDGFR- $\beta$, VEGFR-2, FGFR-1, D114 and Notch-1 in HUVECs (Fig. 4C), in a concentration-dependent manner. Sorafenib 
only downregulated VEGFR-2 and PDGFR- $\beta$ expression in HUVECs, but had no marked effect on the expression of the other factors (Fig. 4C), verifying that sorafenib inhibited endothelial cell proliferation mainly by targeting VEGF signaling.

\section{Discussion}

$\mathrm{As}_{2} \mathrm{O}_{3}$ was firstly introduced as an effective agent with low toxicity for APL treatment by Chinese researchers (37). Since its approval by the FDA for use in leukemia therapy, $\mathrm{As}_{2} \mathrm{O}_{3}$ has also been applied to numerous solid tumors $(38,39)$. However, the mechanism of its anticancer activity in solid tumors is not yet fully understood.

In the present study, in vivo experiments demonstrated that $\mathrm{As}_{2} \mathrm{O}_{3}$ significantly inhibited the growth of NSCLC and SCLC xenografts in a dose-dependent manner. $\mathrm{As}_{2} \mathrm{O}_{3}$ also exhibited a marked anti-angiogenic effect in animal models of lung cancer. In vitro cell proliferation assays were conducted in the present study, which revealed that the inhibitory effect of $\mathrm{As}_{2} \mathrm{O}_{3}$ on NSCLC and SCLC cell growth was not so remarkable as that observed in vivo. In addition, $\mathrm{As}_{2} \mathrm{O}_{3}$ significantly suppressed endothelial cell proliferation. These data suggested that anti-angiogenesis, rather than direct cytotoxicity towards tumor cells, was the main mechanism of the anticancer effect of $\mathrm{As}_{2} \mathrm{O}_{3}$.

The anti-angiogenic effect of $\mathrm{As}_{2} \mathrm{O}_{3}$ has been reported in various studies, both in vivo and in vitro. A previous study reported that 0.5 and $5.0 \mu \mathrm{M} \mathrm{As}_{2} \mathrm{O}_{3}$ caused inhibition of VEGF in leukemic cells, and prevented capillary tube formation in an endothelial cell-differentiation assay (40). It was also reported that $\mathrm{As}_{2} \mathrm{O}_{3}$ delayed gastric cancer xenograft growth, decreased microvessel density, and downregulated VEGFR-1 and VEGFR-2 expression (14). Besides reducing the number of vessels, $\mathrm{As}_{2} \mathrm{O}_{3}$ also influences the vascular morphology and function. Adding $\mathrm{As}_{2} \mathrm{O}_{3}$ into the drinking water for mice induced significant vascular remodeling, with increased sinusoidal endothelial cell capillarization, resulting in decreased permeability and transport function (41). In another study, $\mathrm{As}_{2} \mathrm{O}_{3}(10 \mathrm{mg} / \mathrm{kg}$ i.p.) produced a preferential vascular 'shutdown' in the tumor tissue in a model of methylcholanthrene-induced fibrosarcoma in BALB/c mice, leading to extensive necrosis in the central part of the tumor (42). In addition, ${ }^{99 \mathrm{~m}} \mathrm{Tc}$ clearance and ${ }^{86} \mathrm{Rb}$ uptake in the tumor tissue were decreased, suggesting declined tumor perfusion (42).

In the present study, $\mathrm{As}_{2} \mathrm{O}_{3}$ decreased the number of microvessels in lung cancer xenografts, and it also inhibited HUVEC proliferation significantly at both 24 and $48 \mathrm{~h}$. In addition, $\mathrm{As}_{2} \mathrm{O}_{3}$ reduced the expression of VEGF-A and bFGF in lung cancer cells, as well as that of VEGFR-2 and FGFR-1 in HUVECs. VEGF-A/VEGFR-2 and bFGF/FGFR-1 are both potent stimulating factors of endothelial cell proliferation, which have been previously validated $(43,44)$.

The present results also indicated that $\mathrm{As}_{2} \mathrm{O}_{3}$ disrupted endothelial cell migration, and downregulated MMP-2, MMP-9 and PDGF-BB in lung cancer cells, and PDGFR- $\beta$ in HUVECs. MMPs such as MMP-2 and MMP-9 contribute to basement membrane degradation and ECM remodeling, which allow endothelial cell migration and sprouting (20). PDGF signaling promotes endothelial cell migration through the remodeled ECM and the formation of new blood vessels (45).
The present results confirmed that $\mathrm{As}_{2} \mathrm{O}_{3}$ could inhibit this signaling pathway and thereby disturb HUVEC migration.

Furthermore, the present data revealed that $\mathrm{As}_{2} \mathrm{O}_{3}$ influenced the morphology of microvessels by inducing poorly developed vascular structures in vivo. Tube formation assays on Matrigel were performed to explore the effect of $\mathrm{As}_{2} \mathrm{O}_{3}$ on the number and shape of newly formed microvessels upon stimulation with VEGF-A and bFGF. It was observed that $\mathrm{As}_{2} \mathrm{O}_{3}$ reduced the number of cord formations and destroyed the normal tube structures. This effect helped to distinguish $\mathrm{As}_{2} \mathrm{O}_{3}$ from the well-known angiogenesis-targeted inhibitor sorafenib. In vivo, formation of vascular lumen structures is promoted by Dll4/Notch signaling (46). It has been reported that blockade of Dll4/Notch signaling induced defective maturation of blood vessels with poor perfusion $(28,47)$. According to the present results, $\mathrm{As}_{2} \mathrm{O}_{3}$ reduced the level of Dll4 in lung cancer cells and HUVECs, and reduced the level of Notch-1 in HUVECs. These findings implied that $\mathrm{As}_{2} \mathrm{O}_{3}$ influenced the morphology and function of new vessels in lung cancer, possibly by downregulating D114/Notch signaling.

In summary, the present study demonstrated that $\mathrm{As}_{2} \mathrm{O}_{3}$ could inhibit lung cancer xenograft growth and tumor angiogenesis. It was also observed that $\mathrm{As}_{2} \mathrm{O}_{3}$ could disrupt multiple stages of angiogenesis, including endothelial cell migration, proliferation and network formation, and could regulate the expression of the key signaling molecules involved in these processes. The present findings may provide the experimental basis to extend the indications of $\mathrm{As}_{2} \mathrm{O}_{3}$ and to identify novel therapeutic approaches for lung cancer.

\section{Acknowledgements}

The present study was supported by the National Natural Science Foundation of China (grant no. 81172227, 81672929 and 81602618) and the Research Foundation of Shanghai Municipal Education Commission (grant no. 12ZZ073).

\section{References}

1. Waxman S and Anderson KC: History of the development of arsenic derivatives in cancer therapy. Oncologist 6 (suppl 2): S3-S10, 2001.

2. Chen SJ, Zhou GB, Zhang XW, Mao JH, de Thé H and Chen Z: From an old remedy to a magic bullet: Molecular mechanisms underlying the therapeutic effects of arsenic in fighting leukemia. Blood 117: 6425-6437, 2011.

3. Zhang X, Jia S, Yang S, Yang Y, Yang T and Yang Y: Arsenic trioxide induces $\mathrm{G} 2 / \mathrm{M}$ arrest in hepatocellular carcinoma cells by increasing the tumor suppressor PTEN expression. J Cell Biochem 113: 3528-3535, 2012.

4. Wang X, Jiang F, Mu J, Ye X, Si L, Ning S, Li Z and Li Y: Arsenic trioxide attenuates the invasion potential of human liver cancer cells through the demethylation-activated microRNA-491. Toxicol Lett 227: 75-83, 2014.

5. Gao JK, Wang LX, Long B, Ye XT, Su JN, Yin XY, Zhou XX and Wang ZW: Arsenic Trioxide Inhibits Cell Growth and Invasion via Down-Regulation of Skp2 in Pancreatic Cancer Cells. Asian Pac J Cancer Prev 16: 3805-3810, 2015.

6. Ji H, Li Y, Jiang F, Wang X, Zhang J, Shen J and Yang X: Inhibition of transforming growth factor beta/SMAD signal by MiR-155 is involved in arsenic trioxide-induced anti-angiogenesis in prostate cancer. Cancer Sci 105: 1541-1549, 2014.

7. Wang H, Gao P and Zheng J: Arsenic trioxide inhibits cell proliferation and human papillomavirus oncogene expression in cervical cancer cells. Biochem Biophys Res Commun 451: 556-561, 2014. 
8. Torre LA, Bray F, Siegel RL, Ferlay J, Lortet-Tieulent J and Jemal A: Global cancer statistics, 2012. CA Cancer J Clin 65: 87-108, 2015

9. Li H, Zhu X, Zhang Y, Xiang J and Chen H: Arsenic trioxide exerts synergistic effects with cisplatin on non-small cell lung cancer cells via apoptosis induction. J Exp Clin Cancer Res 28: $110,2009$.

10. Walker AM, Stevens JJ, Ndebele K and Tchounwou PB: Arsenic trioxide modulates DNA synthesis and apoptosis in lung carcinoma cells. Int J Environ Res Public Health 7: 1996-2007, 2010.

11. Lam SK, Li YY, Zheng CY, Leung LL and Ho JC: E2F1 downregulation by arsenic trioxide in lung adenocarcinoma. Int J Oncol 45: 2033-2043, 2014.

12. Zheng CY, Lam SK, Li YY, Fong BM, Mak JC and Ho JC: Combination of arsenic trioxide and chemotherapy in small cel lung cancer. Lung Cancer 82: 222-230, 2013.

13. Jiang F, Wang X, Liu Q, Shen J, Li Z, Li Y and Zhang J: Inhibition of TGF- $\beta / \mathrm{SMAD} 3 / \mathrm{NF}-\kappa \mathrm{B}$ signaling by microRNA-491 is involved in arsenic trioxide-induced anti-angiogenesis in hepatocellular carcinoma cells. Toxicol Lett 231: 55-61, 2014.

14. Xiao YF, Wu DD, Liu SX, Chen X and Ren LF: Effect of arsenic trioxide on vascular endothelial cell proliferation and expression of vascular endothelial growth factor receptors Flt-1 and KDR in gastric cancer in nude mice. World J Gastroenterol 13: 6498-6505, 2007.

15. Aggarwal C, Somaiah N and Simon G: Antiangiogenic agents in the management of non-small cell lung cancer: Where do we stand now and where are we headed? Cancer Biol Ther 13 247-263, 2012

16. Folkman J: Tumor angiogenesis: Therapeutic implications. N Engl J Med 285: 1182-1186, 1971.

17. Weis SM and Cheresh DA: Tumor angiogenesis: Molecular pathways and therapeutic targets. Nat Med 17: 1359-1370, 2011.

18. Carmeliet P and Jain RK: Molecular mechanisms and clinical applications of angiogenesis. Nature 473: 298-307, 2011

19. Bergers G, Brekken R, McMahon G, Vu TH, Itoh T, Tamaki K, Tanzawa K, Thorpe P, Itohara S, Werb Z and Hanahan D: Matrix metalloproteinase-9 triggers the angiogenic switch during carcinogenesis. Nat Cell Biol 2: 737-744, 2000

20. Deryugina EI and Quigley JP: Pleiotropic roles of matrix metalloproteinases in tumor angiogenesis: Contrasting, overlapping and compensatory functions. Biochim Biophys Acta 1803: $103-120,2010$

21. Humphries JD, Byron A and Humphries MJ: Integrin ligands at a glance. J Cell Sci 119: 3901-3903, 2006.

22. Sakurai $\mathrm{T}$ and Kudo M: Signaling pathways governing tumor angiogenesis. Oncology 81 (suppl 1): S24-S29, 2011

23. Andrae J, Gallini R and Betsholtz C: Role of platelet-derived growth factors in physiology and medicine. Genes Dev 22: 1276-1312, 2008.

24. Lohela M, Bry M, Tammela T and Alitalo K: VEGFs and receptors involved in angiogenesis versus lymphangiogenesis. Curr Opin Cell Biol 21: 154-165, 2009.

25. Cao Y, Cao R and Hedlund EM: R Regulation of tumor angiogenesis and metastasis by FGF and PDGF signaling pathways. J Mol Med (Berl) 86: 785-789, 2008.

26. Korc M and Friesel RE: The role of fibroblast growth factors in tumor growth. Curr Cancer Drug Targets 9: 639-651, 2009.

27. Kuhnert F, Kirshner JR and Thurston G: Dll4-Notch signaling as a therapeutic target in tumor angiogenesis. Vasc Cell 3: 20, 2011

28. Noguera-Troise I, Daly C, Papadopoulos NJ, Coetzee S, Boland P, Gale NW, Lin HC, Yancopoulos GD and Thurston G: Blockade of Dll4 inhibits tumour growth by promoting non-productive angiogenesis. Nature 444: 1032-1037, 2006.

29. Ridgway J, Zhang G, Wu Y, Stawicki S, Liang WC, Chanthery Y, Kowalski J, Watts RJ, Callahan C, Kasman I, et al: Inhibition of D114 signaling inhibits tumour growth by deregulating angiogenesis. Nature 444: 1083-1087, 2006.
30. Williams CK, Li JL, Murga M,Harris AL and Tosato G: Up-regulation of the Notch ligand Delta like 4 inhibits VEGF-induced endothelial cell function. Blood 107: 931-939, 2006.

31. Ferrara $\mathrm{N}$ and Kerbel RS: Angiogenesis as a therapeutic target. Nature 438: 967-974, 2005.

32. Cooney MM, van Heeckeren W, Bhakta S, Ortiz J and Remick SC: Drug insight: Vascular disrupting agents and angiogenesis novel approaches for drug delivery. Nat Clin Pract Oncol 3: 682-692, 2006.

33. Yang MH, Zang YS, Huang H, Chen K, Li B, Sun GY and Zhao XW: Arsenic trioxide exerts anti-lung cancer activity by inhibiting angiogenesis. Curr Cancer Drug Targets 14: 557-566, 2014.

34. Xie SL, Yang MH, Chen K, Huang H, Zhao XW, Zang YS and $\mathrm{Li}$ B: Efficacy of arsenic trioxide in the treatment of malignant pleural effusion caused by pleural metastasis of lung cancer. Cell Biochem Biophys 71: 1325-1333, 2015.

35. Cattaneo MG, Pola S, Dehò V, Sanguini AM and Vicentini LM: Alprostadil suppresses angiogenesis in vitro and in vivo in the murine Matrigel plug assay. Br J Pharmacol 138: 377-385, 2003.

36. Takahashi S: Vascular endothelial growth factor (VEGF), VEGF receptors and their inhibitors for antiangiogenic tumor therapy. Biol Pharm Bull 34: 1785-1788, 2011.

37. Shen ZX, Chen GQ, Ni JH, Li XS, Xiong SM, Qiu QY, Zhu J, Tang W, Sun GL, Yang KQ, et al: Use of arsenic trioxide (As2O3) in the treatment of acute promyelocytic leukemia (APL): II Clinical efficacy and pharmacokinetics in relapsed patients. Blood 89: 3354-3360, 1997.

38. Ma Y, Wang J, Liu L, Zhu H, Chen X, Pan S, Sun X and Jiang H: Genistein potentiates the effect of arsenic trioxide against human hepatocellular carcinoma: Role of Akt and nuclear factor- $\kappa \mathrm{B}$. Cancer Lett 301: 75-84, 2011.

39. Guo W, Tang XD, Tang S and Yang Y: Preliminary report of combination chemotherapy including Arsenic trioxide for stage III osteosarcoma and Ewing sarcoma. Zhonghua Wai Ke Za Zhi 44: 805-808, 2006 (In Chinese)

40. Roboz GJ, Dias S, Lam G, Lane WJ, Soignet SL, Warrell RP Jr and Rafii S: Arsenic trioxide induces dose- and time-dependent apoptosis of endothelium and may exert an antileukemic effect via inhibition of angiogenesis. Blood 96: 1525-1530, 2000.

41. Straub AC, Stolz DB, Ross MA, Hernández-Zavala A, Soucy NV, Klei LR and Barchowsky A: Arsenic stimulates sinusoidal endothelial cell capillarization and vessel remodeling in mouse liver. Hepatology 45: 205-212, 2007.

42. Lew YS, Brown SL, Griffin RJ, Song CW and Kim JH: Arsenic trioxide causes selective necrosis in solid murine tumors by vascular shutdown. Cancer Res 59: 6033-6037, 1999.

43. Ferrara N, Gerber HP and LeCouter J: The biology of VEGF and its receptors. Nat Med 9: 669-676, 2003

44. Lindner V, Majack RA and Reidy MA: Basic fibroblast growth factor stimulates endothelial regrowth and proliferation in denuded arteries. J Clin Invest 85: 2004-2008, 1990.

45. Wang D, Huang HJ, Kazlauskas A and Cavenee WK: Induction of vascular endothelial growth factor expression in endothelial cells by platelet-derived growth factor through the activation of phosphatidylinositol 3-kinase. Cancer Res 59: 1464-1472, 1999.

46. Kume T: Novel insights into the differential functions of Notch ligands in vascular formation. J Angiogenes Res 1: 8, 2009.

47. Scehnet JS, Jiang W, Kumar SR, Krasnoperov V, Trindade A, Benedito R, Djokovic D, Borges C, Ley EJ, Duarte A and Gill PS: Inhibition of Dll4-mediated signaling induces proliferation of immature vessels and results in poor tissue perfusion. Blood 109: 4753-4760, 2007. 